\title{
Alternatív dohánytermékek használata fesztiválon részt vevő fiatal felnőttek körében
}

\author{
Use of Alternative Nicotine and Tobacco Products Among Young Adults \\ Participating in a Hungarian Festival
}

Szerzők: $\quad$ Torma Albert ${ }^{a}$, Fazekas-Pongor Vince ${ }^{b}$, Terebessy András ${ }^{b}$, Pénzes Melinda ${ }^{b} \square$ a: Országos Rendőr-főkapitányság, Személyügyi Főigazgatóság, Humánigazgatási Szolgálat, Rendvédelmi Egészségügyi Felülvizsgáló Főosztály, b: Semmelweis Egyetem, Általános Orvostudományi Kar, Népegészségtani Intézet

Beküldve: $\quad$ 2019. 04. 23.

doi: $\quad$ 10.24365/ef.v60i4.463

\begin{abstract}
Összefoglaló:
Bevezetés: Az alternatív nikotinos- és dohánytermékek (ANDT) a nyugati társadalmakban egyrészt régóta léteznek (például szivar, kézzel sodort cigaretta, pipa, sznüsz, rágódohány, tubák), illetve olyan újabb termékek, amelyek használata az elmúlt években drámaian fokozódott, mint például a vízipipa vagy az e-cigaretta. A szabadtéri zenei fesztiválokat látogató fiatalok körében a legális és illegális szerek fokozott használata jellemző. Tanulmányunk célja egy hazai zenei fesztiválon részt vevő, felsőoktatásban tanuló fiatal felnőttek ANDT használatának és az arra hajlamosító tényezők feltárása.
\end{abstract}

Módszertan: Keresztmetszeti, anonim, önkitöltős kérdőíves vizsgálatunkat 2015 júliusban az EFOTT nyári fesztiválon részt vevő, felsőoktatásban tanuló fiatal felnőttek körében ( $n=523$, 45,2\% nő) végeztük. Leíró statisztikai elemzések mellett többváltozós logisztikus regressziómodellekkel vizsgáltuk az ANDT-használat összefüggését szociodemográfiai, dohányzással kapcsolatos és egyéb magyarázó változókkal.

Eredmények: Mintánk 30,4\%-a alkalmanként dohányzott, 18,9\%-a pedig naponta dohányzónak vallotta magát. A résztvevők 48,8\%-a egyféle, 14,3\% legalább kétféle ANDT-t használt, 36,9\% pedig semmilyen ANDT-t nem használt. Legalább havonta egyszer a résztvevők 11,0\%-a használt vízipipát, 2,2\%-a e-cigarettát, $1 \%$ körüli vagy az alatti arányban pedig pipát, szivart, szivarkát és füstmentes dohánytermékeket. Az alkalmankénti és legalább havi gyakoriságú együttes használatot tekintve a vízipipa $(59,0 \%)$, szivar $(8,3 \%)$ és e-cigaretta $(6,3 \%)$ bizonyult a legnépszerúbbnek. Az alkalmanként dohányzók 67,9\%-a használt havonta vagy alkalmanként vízipipát, 10,3\%-a e-cigarettát; a naponta dohányzók $62,7 \%$ vízipipát és $14,6 \%$-a e-cigarettát, a nemdohányzók 52,1\%-a vízipipát és 0,8\%-a e-cigarettát. Az alkalmanként ( $E H=5,97$, $95 \% \mathrm{Cl}=2,35-15,14)$, illetve naponta dohányzás ( $\mathrm{EH}=4,41,95 \% \mathrm{Cl}=1,69-11,52)$ mellett a problémás alkoholhasználat $(\mathrm{EH}=3,14,95 \% \mathrm{Cl}=1,12-8,76)$, a férfi nem $(\mathrm{EH}=2,98,95 \% \mathrm{Cl}=1,35-6,58)$, a havi $<30000$ forint költôpénz ( $E H=2,98,95 \% \mathrm{Cl}=1,29-6,86)$ és a nagyobb szenzoros élménykereső hajlam ( $\mathrm{EH}=1,08,95 \% \mathrm{Cl}=1,01-1,15)$ bizonyultak a többes ANDT-használat szignifikáns előrejelzőinek szemben az ANDT-használat mellőzésével.

Következtetések: Eredményeink alapján a felsőoktatásban tanuló, szabadtéri zenei fesztiválon részt vevő fiatal felnőttek ANDT-használata számottevő, és jól azonosíthatók az ANDT-használók kiemelt kockázati csoportjai. Éppen ezért a fiatal felnőtt korosztályban is szükség volna többszintű dohányzásprevenciós tevékenységekre.

Kulcsszavak: dohányzás; dohánytermékek; fesztivál, felsőoktatás; hallgatók 


\section{Summary:}

Introduction: Alternative nicotine and tobacco products (ANTP) includes long-standing tobacco products in Western societies (e.g., cigar, roll-your-own cigarette, pipe, snus, chewing tobacco, snuff) and new products which use have increased dramatically in recent years, e.g., waterpipe and e-cigarette. Explicit use of legal and illegal substances is common among young people visiting outdoor music festivals. Our study aimed to explore ANTP use and its predictors among young adults studying in higher education and participating in a Hungarian music festival.

Methods: Our cross-sectional study was conducted among young adults ( $n=523,45.2 \%$ females) studying in higher education and participating in the EFOTT summer festival in July, 2015, using anonymous, self-administered questionnaire. Beside descriptive analyses, multivariate logistic regression models were used to explore the relationship of ANTP use with sociodemographic variables, smoking and other covariates.

Results: In our sample, $30.4 \%$ of participants were occasional smokers and $18.9 \%$ self-reported daily smoking. $48.8 \%$ of participants used one type, $14.3 \%$ used at least two ANTPs while $36.9 \%$ did not use any ANTPs at all. At least once a month, $11.0 \%$ of participants used waterpipe, $2.2 \%$ e-cigarette, and $1 \%$ or less used pipe, cigar, cigarillo, and smokeless tobacco products. Combining occasional and at least once a month use, waterpipe (59.0\%), cigar (8.3\%) and e-cigarette (6.3\%) were the most popular products. Regarding occasional smokers, $67.9 \%$ of them used waterpipe and $10.3 \%$ used e-cigarette at least once in a month; $62.7 \%$ and $14.6 \%$ of daily smokers used waterpipe and e-cigarette, respectively; while $52.1 \%$ and $0.8 \%$ of nonsmokers used waterpipe and e-cigarette, respectively. Besides occasional (OR=5.97, $95 \% \mathrm{Cl}=2.35-15.14))$ and daily smoking $(\mathrm{OR}=4.41,95 \% \mathrm{Cl}=1.69-11.52)$, problematic alcohol use $(\mathrm{OR}=3.14,95 \% \mathrm{Cl}=1.12-8.76)$, male gender $(\mathrm{OR}=2.98,95 \% \mathrm{Cl}=1.35-6.58),<30000$ HUF money for free use $(\mathrm{OR}=2.98,95 \% \mathrm{Cl}=1.29-6.86)$, and greater sensation seeking propensity $(\mathrm{OR}=1.08,95 \% \mathrm{Cl}=1.01-1.15)$ were significant predictors of multiple ANTP use compared to ANTP non-use.

Conclusions: According to our results, ANTP use of young adults studying in higher education and participating in an outdoor music festival is remarkable, and high risk groups of ANTP users were clearly identified. Therefore, multi-level smoking prevention would be needed in the young adult population.

Keywords: smoking; tobacco products; festival; higher education; students

\section{BEVEZETÉS}

Alternatív nikotinos- és dohánytermékek (ANDT) alatt értünk a nyugati világban egyrészt régóta létező dohánytermékeket, például szivar, kézzel sodort cigaretta, pipa, snus (sznüsz), rágódohány, tubák, illetve olyan újabb termékeket, amelyek használata az elmúlt években drámaian fokozódott, mint például a vízipipa vagy az elektronikus cigaretta (e-cigaretta). ${ }^{1}$ Az ANDT-k alternatívát jelentenek a gyárilag előállított cigarettához képest a fogyasztók számára, leggyakrabban egészségügyi ártalomcsökkentés, kényelmi vagy anyagi megfontolásokból.,3,4,5 Ugyanakkor számos tévhit él a köztudatban az ANDT-kel kapcsolatban, mert mind a serdülők, mind a felnőttek gyakran tévesen biztonságosabbnak, egészségre kevésbé ártalmas- nak vélik őket, szemben a gyárilag előállított cigarettákkal. ${ }^{2,6}$ Ám újabban bizonyossá vált, hogy önmagukban és az ún. többes dohányhasználat útján egyértelmúen fokozzák a nikotinfüggőség, egyes daganatos, szív- és érrendszeri betegségek, valamint számos egyéb, dohányzással összefüggő kórkép kialakulásának a kockázatát. ${ }^{2,6}$ Az e-cigaretta egészségre gyakorolt rövid- és hosszú távú, kedvező vagy kedvezőtlen hatásáról még nem áll rendelkezésre elegendő és egyértelmú bizonyíték, azonban használatuk számos népegészségügyi szempontból aggályos kérdést vet fel. ${ }^{7}$ Az ANDT-használat fiatalok esetében egyrészt a fokozott nikotinexpozíció révén felgyorsíthatja a nikotinfüggőség kialakulását, másrészt növelheti a nagyobb intenzitású, "erős” dohányzásba átmenet valószínűségét. ${ }^{8} \mathrm{~A}$ nemdohányzó fiatalok körében pedig „kapuhatása” lehet 
az ANDT-használatnak, azaz elősegítheti a cigarettázás elkezdését. ${ }^{6,9,10}$ Az ANDT-használat többnyire a cigarettahasználattal együttesen fordul elő, izoláltan pedig ritkábban. Több tanulmányban azt találták, hogy legnagyobb arányban a cigarettázó fiatal felnőttek használtak egyidejűleg egyéb dohányterméket is. $11,12,13,14$

A fiatal felnőttkor kritikus periódus az egészségkárosító magatartásformák, mint a dohányzás és alkoholfogyasztás iránti elköteleződés szempontjából. A téves biztonságtudat mellett az ANDT-ket sok fiatal vonzónak, izgalmasnak és divatosnak találja, szemben a cigarettával, amit az utóbbi években a közvélekedés egyre kevésbé tart elfogadhatónak, elsősorban annak használatát korlátozó dohányzáspolitikai intézkedések következtében. ${ }^{2,6}$ Különféle társas helyzetekben eltérő dohánytermékeket preferálhatnak a fiatalok, mint például a vízipipát társasági eseményeken. ${ }^{15} \mathrm{Az}$ ízesített ANDT-k többsége különösen tetszetős lehet a fiatalok számára. A dohányipar évtizedek óta használ a termékeiben ízesítő adalékanyagokat annak érdekében, hogy háttérbe szorítsák a dohány ízének természetes „keménységét” és az ezzel járó irritáló érzéseket. ${ }^{16}$ Ugyancsak vonzó technikai és ízbeli újdonságok lehetnek a fiatalok számára a különböző generációjú és több száz féle cserélgethető alkatrésszel rendelkező e-cigaretták, amelyekhez ma már több mint 7000-féle ízesítésű e-liquid (e-cigaretta patronjába tölthető folyadék) kapható. ${ }^{17,18}$ Az ANDTkipróbálásban további ösztönző ereje lehet a kortárshatásnak, a hasonlóan újdonság-, illetve szenzoros élménykereső barátok választásának, valamint a termékek kedvezőbb társadalmi megítélésének. ${ }^{1,6,15,19}$ A szenzoros élménykeresés a változatos, új, intenzív élmények, tapasztalatok szerzésére irányuló stabil személyiségvonás, amely számos egészségkárosító magatartással és kockázatos tevékenységgel áll összefüggésben. ${ }^{20}$ Fiatal felnőttek esetében több tanulmány is egyértelmú összefüggést jelzett a magasabb fokú szenzoros élménykeresés és ANDT-használat között, egyes esetekben a dohányzók, máskor viszont a nemdohányzók körében. 1,12,21 Az alkoholfogyasztás és a dohányzás gyakran egymással párban járó viselkedések a fiatalok körében. Nevezetesen, az alkoholfogyasztás egyrészt elősegíti, másrészt mentségül is szolgálhat a dohányzásra, különösen az alkalmi dohányosok körében. ${ }^{22}$ Továbbá, az alkoholt gyakrabban fogyasztó fiatalok az ANDT-ket is nagyobb valószínúséggel próbálják ki. ${ }^{1,12,23}$

A fiatal felnőttek ANDT-használatára vonatkozóan kevés hazai adat áll rendelkezésre. A zenei fesztiválok jelentős színtérnek számítanak a deviáns vagy társadalmi normákat megsértő viselkedések felbukkanásában, és akár a dohányzás elkezdésének színterei is lehetnek. ${ }^{24}$ A fiatal felnőttek speciális populációját képezi a szabadtéri zenei fesztiválokat, mint rekreációs színtereket látogatók csoportja, akik körében a legális és illegális szerek fokozottabb használata jellemzőbb. ${ }^{24,25,26}$ Egy ilyen fesztivál éppen ezért az ANDT-használatnak feltérképezésére is megfelelő színtér lehet. Tanulmányunk célja egy hazai rendezvényen részt vevő és felsőoktatásban tanuló fiatal felnőttek ANDT-használatának feltérképezése, amely által kutatásunk mélyebb betekintést nyújthat ezen korcsoport fogyasztási mintázataiba. Másrészt az ANDT fogyasztásra hajlamosító tényezők meghatározása értékes információkat szolgáltathat a jövőbeli hazai preventív programok megtervezéséhez.

\section{MÓDSZERTAN}

A "Magyar fiatal felnőttek egészségmagatartása” című kérdőíves keresztmetszeti adatfelvételünk 2015. július 14-19. között zajlott a 40. EFOTT (Egyetemisták és Főiskolások Országos Turisztikai Találkozója) fesztiválon, Velencén. Azok a résztvevők kerültek a mintába, akik önkéntesen ellátogattak a Nemzeti Egészségfejlesztési Intézet életmódtanácsadó helyszínére. Az önkitöltős, anonim kérdőív megválaszolása előzetes felmérésünk alapján 10 percet vett igénybe. Képzett kérdezőbiztosok szóban és írásban is ismertették az adatgyűjtés célját a résztvevőkkel, valamint biztosították őket az adatok bizalmas kezeléséről. Összesen 596 fesztiválozó, vagyis a 40. EFOTT fesztivál 103500 résztvevőjének 0,58\%-a vett részt a nem reprezentatív kutatásban. Jelen tanulmány mintájából kiemeltük azokat, akik a 18-35 éves életkori tartományon kívül estek ( $n=54)$, akik a kérdőívet hiányosan töltötték ki ( $n=28)$, valamint akik a kérdőívben nem válaszoltak az alternatív dohánytermékek használatával kapcsolatos kérdésekre $(n=21)$. Az elemzésbe bevont minta mindezek alapján 523 főből állt. A kutatást a Semmelweis Egyetem Tudományos Etikai Bizott- 
sága hagyta jóvá (SE TUKEB szám: 115/2015).

Az önkitöltős, anonim kérdőív 33 kérdése különböző szerhasználati, életmódi és magatartásra vonatkozó kérdéseket tartalmazott. Jelen tanulmányban a következő változókat vizsgáltuk az elemzésekben.

A szociodemográfiai változók között szerepelt az életkor, amelyet két kategóriára osztottunk az elemzésekhez (18-25 éves vs. 26-35 éves korcsoportok), a nem (férfi/nő), és a jelenlegi tanulmányok megnevezése. Utóbbi változó esetében a válaszolók a www.felvi.hu felsőoktatási elektronikus portál által csoportosított 14 féle szak közül választhattak, valamint „egyéb” és „nem tanulok” kategóriákat is megadtunk. ${ }^{27}$ Mindezeket az elemzések céljára négykategóriás változóvá csoportosítottuk: 1) egészségorientált képzés (egészségtudomány, sporttudomány, társadalomtudomány, természettudomány); 2) bölcsészjellegű képzés (bölcsészettudomány, jogtudomány, múvészet, múvészetközvetítés, pedagógia); 3) nem egészségorientált képzés (agrár, gazdaságtudomány, informatika, műszaki tudományok, közigazgatási-rendészeti-katonai); 4) egyéb/nem tanul. A havonta rendszeresen ismétlődő kiadásokon kívül, a szabadon elkölthető pénzösszeget hat kategória jelölte, amelyeket bináris változóvá alakítottunk (<30000 forint/hó vs. $\geq 30000$ forint/hó). Az egyetemi/fóiskolai tanulmányok melletti munkavállalásról (igen/nem) szintén nyilatkoztak a résztvevők.

A szakirodalom általában az ANDT-hez sorolja a kézzel sodort cigarettát, azonban fogyasztásának magas hazai aránya miatt vizsgálatunkban a dohányzás fogalmába soroltuk. ${ }^{28}$ Így a dohányzást a jelenlegi, gyárilag előállított, illetve saját maguk által sodort cigarettahasználat alapján mértük (nem dohányzik; alkalmanként dohányzik; naponta dohányzik). Az ANDT-k közül a vízipipa, e-cigaretta, szivar, szivarka, pipa és füstmentes dohánytermékek (snus, rágódohány, tubák) használatát a kitöltők a „Használtál-e/használsz-e egyéb dohányterméket?" kérdésre hat válaszlehetőség alapján jelölhették: 1) nem, soha nem próbáltam; 2) nem, de már kipróbáltam; 3) igen, alkalmanként, ritkábban, mint havonta; 4) igen, rendszeresen, legalább havonta egyszer; 5) igen, naponta; 6) már nem használom rendszeresen. A hat kategóriát egyes elemzésekben négy kategóriává redukáltuk (nem próbálta; kipróbálta; alkalmanként használja; rendszeresen, legalább havonta egyszer használja). Más elemzésekhez az elmúlt havi rendszeres használat többnyire alacsony értékei miatt az alkalmankénti és a rendszeres használat kategóriákat összevontan elemeztük „ANDT-t használ” kategóriaként. További elemzésekben a háromkategóriás függő változót a használt ANDT-k száma alapján alakítottuk ki (nem használ ANDT-t; egyféle ANDT-t használ; $\geq 2$ ANDT-t használ).

A szenzoros élménykeresést a nyolctételes rövid szenzoros élménykeresés-skála (Brief SensationSeeking Scale, BSSS) magyar változatával mértük. ${ }^{29}$ A skála egy szenzoros élménykeresés pontszámot eredményez, az összesített pontérték 0 és 32 között változhatott. A skála eredeti mintán mutatott belső konzisztenciája megfelelő volt (Cronbach- $\alpha=0,76)$, saját mintánkon pedig úgyszintén (Cronbach$\alpha=0,74) .{ }^{29}$

A problémás alkoholfogyasztás mérésének eszköze az AUDIT (Alcohol Use Disorders Identification Test - Alkoholhasználat Zavarainak Szúrőtesztje) volt, amelynek 10 tétele három témakört vizsgál: az alkoholfogyasztás mértékét, az alkoholfüggőséget és az alkoholfogyasztással összefüggő problémákat. ${ }^{30}$ A skála összesített pontértéke 0 és 40 között változhatott, belső megbízhatóságának átlagértéke szisztematikus áttekintő tanulmányok alapján Cronbach- $\alpha=0,80$, saját mintánkon pedig Cronbach$\alpha=0,72 .{ }^{31} \mathrm{~A}$ problémás alkoholhasználatot 8 ponttól számítottuk. ${ }^{30}$

Az adatokat IBM SPSS 24.0 statisztikai programmal elemeztük. A leíró statisztikai analízis során átlagés szórás-számításokat végeztünk. Kategorikus változók közötti összefüggések vizsgálatára kereszttáblás elemzést alkalmaztunk Pearson-féle khinégyzet próbával, illetve folytonos változók esetében egyszempontos varianciaanalízist és független mintás t-próbát. Az összefüggések hátterének feltárása többváltozós logisztikus regresszió modellekkel történt, amelyekben azt vizsgáltuk, hogy mi jelzi előre az ANDT-használatot szociodemográfiai, dohányzással kapcsolatos és egyéb magyarázó változók mentén. Mindegyik változó esetében esélyhányadost (EH) számítottunk 95\%-os konfidencia-intervallum (Cl) mellett. Valamennyi elemzés eredményét $p<0,05$ érték esetén tekintettük szignifikánsnak. 


\section{EREDMÉNYEK}

A minta leíró jellemzői

A minta átlagéletkora 23,0 év volt (szórás: 3,54), a fiatalabb korcsoport és a férfiak jelentősen nagyobb arányban vettek részt a kutatásban. Felsőoktatási tanulmányi területnek a válaszadók fele a nem egészségorientált képzéseket jelölte meg, míg nagyjából egyötödük nem tanult, vagy egyéb területen tanult. [1. táblázat] A résztvevőknek nagyjából 40\%-a havonta $\geq 30000$ forint költőpénzzel rendelkezett, a férfiak szignifikánsan többen, mint a nők $\left(47,0 \%\right.$ vs. $\left.37,9 \% ; \chi^{2}{ }_{(1)}=4,297 ; p=0,038\right)$. A tanulmányok melletti munkavállalás a minta $60 \%$-ára volt jellemző, ebben a tekintetben a férfiak és nők nem különböztek egymástól. A válaszolók fele vallotta magát nemdohányzónak, mintegy egyötödük pedig naponta dohányzott. Az alkalmi dohányzás a nők (32,6\% vs. $28,3 \%)$, míg a napi rendszerességú dohányzás a férfiak körében fordult elő gyakrabban (19,4\% vs. $18,0 \%)$, azonban a különbség nem volt szignifikáns $\left(\chi^{2}(2)=1,151 ; p=0,562\right)$. A férfiak szignifikánsan magasabb pontszámot értek el a szenzoros élménykeresés-skálán, mint a nők [18,4 (szórás: $5,74)$ vs. 17,3 (szórás: 5,68 ); $t_{(498)}=2,63 ; p=0,024$ ]. Az AUDIT szúrőteszt alapján a résztvevők kétharmada problémás alkoholfogyasztónak bizonyult, a férfiak tendenciózusan többen, mint a nők $(69,1 \%$ vs. $\left.60,6 \% ; \chi^{2}(1)=3,830 ; p=0,050\right)$.

\section{Az alternatív nikotinos- és dohánytermékek használatának jellemzői}

Az ANDT-használatot nézve, amennyiben az elmúlt havi használatot tekintjük rendszeres ANDT-használatnak, a minta közel 11,0\%-a használt rendszeresen vízipipát, 2,2\%-a e-cigarettát, $1 \%$ körüli vagy az alatti arányban pedig pipát, szivart, szivarkát és füstmentes dohánytermékeket. [1. ábra] A használt ANDT-k számát illetően a minta közel fele csak egyféle ANDT-használatról számolt be, 14,3\% azonban legalább kétféle ANDT-t használt, míg nagyjából harmada semmilyen ANDT-t nem használt. Az egyféle ANDT-használat jellemzőbb volt a fiatalabb korcsoportra, nőkre, havi <30 000 forint költőpénzzel rendelkezőkre és alkalmanként dohányzókra. [1. táblázat] A legalább kétféle ANDT-használat ugyancsak a fiatalabb korcsoport és kevesebb költőpénzzel rendelkezők, továbbá a férfiak, naponta dohányzók, fokozottabban szenzoros élménykeresők és problémás alkoholhasználók körében bizonyult szignifikánsan gyakoribbnak. Az egyféle ANDThasználók túlnyomórészt a vízipipát $(95,7 \%)$, míg lényegesen kisebb arányban az e-cigarettát (2,0\%), szivarkát (1,2\%), füstmentes dohánytermékeket $(0,8 \%)$, illetve pipát $(0,4 \%)$ használták. Az egyes ANDT-k használatának nemek szerinti különbségét nézve, a nőkhöz képest a férfiak szignifikánsan nagyobb arányban használtak alkalmanként vagy rendszeresen szivart $\left(4,8 \%\right.$ vs. $10,8 \%, \chi^{2}(2)=50,250$; $p<0,001)$, szivarkát $\left(5,2 \%\right.$ vs. $7,6 \%, \chi_{(2)}^{2}=22,408$; $p<0,001)$, pipát $\left(1,7 \%\right.$ vs. $5,1 \%, \quad \chi_{(2)}^{2}=18,089$; $\mathrm{p}<0,001)$ és füstmentes dohányterméket $(2,6 \%$ vs. $\left.4,8 \%, \quad \chi_{(2)}^{2}=14,978 ; \quad p=0,001\right)$. Szemben a havi

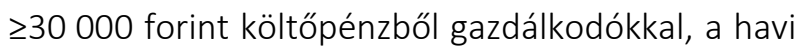
<30 000 forint költőpénzzel rendelkező válaszolók jelentősen nagyobb arányban számoltak be a vízipipa $\left(52,1 \%\right.$ vs. $\left.65,3 \%, \chi^{2}(2)=19,985 ; p<0,001\right)$, a szivarka $\left(6,2 \%\right.$ vs. $\left.7,5 \%, \chi^{2}(2)=13,133 ; p=0,001\right)$ és a pipa $\left(2,8 \%\right.$ vs. $\left.4,5 \%, \chi^{2}(2)=6,747 ; p=0,034\right)$ alkalmankénti vagy rendszeres használatáról. Dohányzói státusz szerint vizsgálva, a nemdohányzók közel fele használt valamilyen rendszerességgel vízipipát, míg néhányan szivarkát, füstmentes dohányterméket vagy e-cigarettát. [2. táblázat] $\mathrm{Az}$ alkalmanként dohányzóknak több mint fele vízipipahasználó is volt, valamint bár lényegesen kevesebben, de e-cigarettát, szivarkát vagy pipát is használtak. A naponta dohányzók esetében $40 \%$ jelezte, hogy vízipipát is szokott használni, és mindössze 2,1\%-uk jelölte meg az e-cigarettát mint egyetlen használt ANDT-t. A legalább kétféle ANDT-t használók többsége jelezte, hogy vízipipát használ $(83,6 \%)$, míg ennél kisebb arányban használták a szivart (58,9\%), szivarkát $(44,4 \%)$, e-cigarettát $(37,5 \%)$, pipát $(24,7 \%)$ és füstmentes dohánytermékeket $(23,6 \%)$. A többféle ANDT-t használó nemdohányzók elsősorban a vízipipát, szivart és füstmentes dohánytermékeket kombinálták, az alkalmanként dohányzók pedig a vízipipa és szivar mellett a szivarkát és e-cigarettát használták. A naponta dohányzók esetében azonban a vízipipa mellett az e-cigaretta és a szivarka volt a leggyakoribb kombináció.

Többváltozós bináris logisztikus regressziós modellekben vizsgáltuk a használt ANDT-k számával összefüggést mutató magyarázó változókat. [3. táblázat] Az alkalmanként dohányzók a nemdohányzókhoz 
képest közel kétszer nagyobb eséllyel ( $E H=1,89$, $95 \% \mathrm{Cl}=1,11-3,20, p=0,019)$ voltak egyféle ANDT-t használók, mint ANDT-t nem használók, illetve a fiatalabb korcsoport is tendenciózusan nagyobb valószínúséggel tartozott az egyféle ANDT-t használó csoportba ( $E \mathrm{H}=1,85,95 \% \mathrm{Cl}=0,99-3,44, \mathrm{p}=0,054)$. $\mathrm{Az}$ alkalmanként (EH=5,97, 95\% Cl=2,35-15,14, $p<0,001)$ ), illetve naponta dohányzás ( $E H=4,41$, $95 \% \mathrm{Cl}=1,69-11,52, p=0,002)$ mellett a problémás alkoholhasználat $\quad(\mathrm{EH}=3,14, \quad 95 \% \mathrm{Cl}=1,12-8,76$, $p=0,029)$, a férfi nem $(E H=2,98,95 \% \mathrm{Cl}=1,35-6,58$, $p=0,007)$, a havi $<30000$ forint költôpénz ( $E H=2,98$, $95 \% \mathrm{Cl}=1,29-6,86, \mathrm{p}=0,010)$, és a nagyobb szenzoros élménykereső hajlam ( $\mathrm{EH}=1,08,95 \% \mathrm{Cl}=1,01-$ 1,15, p=0,033) bizonyultak a többes ANDT-használat szignifikáns előrejelzőinek, szemben az ANDThasználat mellőzésével. A többféle ANDT-t használók nagyobb eséllyel tartoztak a naponta dohányzók ( $\mathrm{EH}=4,35,95 \% \mathrm{Cl}=1,79-10,56, \mathrm{p}=0,001)$, problémás alkoholhasználók $\quad(\mathrm{EH}=2,78, \quad 95 \% \mathrm{Cl}=1,07-7,20$, $p=0,035)$ és a férfiak $(E H=2,40,95 \% C l=1,18-4,88$, $\mathrm{p}=0,016)$ közé az egyféle ANDT-t használókhoz képest.

\section{MEGBESZÉLÉS ÉS KÖVETKEZTETÉSEK}

Eredményeink szerint a nyári fesztiválon részt vevő fiatal felnőttek közel kétharmada használt legalább egyféle ANDT-t, amelyek közül a vízipipa bizonyult a legnépszerúbbnek. Az alkalmanként és a naponta dohányzók körülbelül kétharmada, a nemdohányzóknak pedig több mint fele használt vízipipát. A vízipipa népszerűségének magyarázata lehet, hogy a fiatalok körében társasági eseményeken elfogadott a használata, mivel segíti a társas interakciókat, és tévesen az egészségre kevésbé ártalmasnak vélik, szemben a cigarettával. ${ }^{13,15}$ Különösen aggasztó a nemdohányzók körében tapasztalt magas vízipipa-használat, amellyel akut és esetleg krónikus egészségkárosító hatásnak teszik ki magukat a társasági kívánalmak érdekében. A második legnépszerúbb dohánytermék a szivar volt, noha használati gyakorisága jelentősen elmaradt a vízipipáétól. Az alkalmanként és naponta dohányzók nagyjából 12\%-a, míg a nemdohányzók közel 5\%-a szívott alkalmanként vagy legalább havi gyakorisággal szivart. A szivar kedveltségének egy lehetséges magyarázata, hogy a fiatalok sokkal természetesebb dohányterméknek és ezáltal az egészségre kevésbé károsnak gondolják, mint a gyári cigarettát. ${ }^{32}$ A szivarka használati gyakorisága nem sokkal maradt el a szivarétól az egyes dohányzói csoportokban. A pipázás és a füstmentes dohánytermékek használata bizonyult a legkevésbé népszerünek minden dohányzói csoportban, összességében mintánk közel 4\%-a használta alkalmanként, illetve rendszeresen ezeket a dohánytermékeket. Felnőttek és serdülők körében a hazai vonatkozású vizsgálatok még ennél is alacsonyabb használati gyakoriságot tapasztaltak a pipázást és füstmentes termékeket illetően. ${ }^{28,33,34,35,36} \mathrm{~A}$ népszerūtlenség hátterében állhat, hogy a pipázást a fiatalok nem tartják divatosnak, míg a füstmentes dohánytermékek fogyasztásának nincs jelentős hagyománya hazánkban, valamint a füst nélküli dohánytermékek forgalmazása nem engedélyezett Magyarországon. Bár néhány vizsgálatban magasnak találták a nemdohányzók e-cigaretta használatát, ${ }^{34,37}$ nemdohányzó válaszadóink kevesebb mint 1\%-a használta alkalmanként vagy legalább havonta. Azonban mintánkban az alkalmanként, illetve naponta dohányzók 10,3\%-a, illetve 14,6\%-a nyilatkozott hasonlóképpen, ami jelentősen magasabb arány más magyar adatokhoz képest. ${ }^{33}$ Ennek okaként figyelembe kell venni, hogy mintánkat a fiatal felnőttek speciális populációja képezi, akik körében fokozottabb lehet a szerhasználat. Ugyanakkor az elmúlt havi e-cigaretta használat közel megduplázódott egy 2014-ben, szintén nyári fesztiválon részt vevő fiatal felnőttek mintájában feltártakhoz képest $(1,2 \%){ }^{38}$ és más hazai tanulmányok is alacsonyabb használati gyakoriságot jeleztek. ${ }^{39,40}$ Ennek okaként feltételezhető, hogy az e-cigaretta népszerúsége, még ha ugyan kismértékben, de hazánkban is évről évre növekszik a fiatal felnőtt korosztályban.

Eredményeink alapján úgy tűnik, hogy egyes ANDTk használata népszerúbb a férfiak körében, mint a nőknél. A szivar, szivarka, pipa és füstmentes dohánytermékek használata feltételezhetően kevésbé vonzó a nők számára talán azért is, mert ezen dohánytermékek fogyasztása tradicionálisan a férfias viselkedési normák közé tartozik. ${ }^{41} \mathrm{~A}$ többes ANDT-használat férfiak körében tapasztalt magasabb gyakorisága párhuzamba állítható más, hazai és nemzetközi kutatások eredményeivel. ${ }^{42} \mathrm{~A}$ kevesebb költőpénzzel rendelkezők körében tapasztalt többes ANDT-használat általános jelenségnek mondható. Ennek hátterében állhat, hogy az alacso- 
nyabb jövedelmi státuszú egyének körében nemcsak a cigaretta, de más dohánytermékek használata is gyakoribb, amely utalhat az erősebb nikotinfüggőségükre. ${ }^{43}$ Emellett gyakran az alternatív dohánytermékeket, mint például mintánkban is a vízipipázást vagy a pipázást tévesen egészségesebbnek vélik, szemben a cigarettázással. 2,3,32 Bár egyes dohánytermékek, elsősorban a szivarka ára megfizethetőbb lehet a kevesebb költőpénzzel rendelkező fiatalok számára, szemben más dohánytermékek árával, ${ }^{44}$ az árnak csak részben lehet szerepe a használatban. Ennek oka, hogy a fiatalok gyakran közösen, különösen társas helyzetekben egymással megosztva használják a vízipipát, csökkentve így az egy före jutó költségeket. ${ }^{45}$

Tanulmányunkban az alkalmi dohányzó fiatal felnőttek használtak legnagyobb eséllyel egy- vagy többféle ANDT-t a többi dohányzói csoporthoz képest, csakúgy mint más hasonló korú fiatalok körében végzett vizsgálatokban.1,12,21 Mintánk jelentős részét, közel egyharmadát képezték az alkalmanként dohányzók, akiknek egy része feltételezhetően korábban sohasem dohányzott napi rendszerességgel, másik része viszont felhagyott ezzel és csak alkalmi dohányzóvá vált. Mindezt azért érdemes figyelembe venni, mert a „sohasem napi dohányzó alkalmi dohányosok" az ANDT használattal nagyobb mértékú nikotinexpozíciónak teszik ki magukat, potenciálisan növelve így rendszeres dohányzóvá válásuk kockázatát. A „korábbi napi dohányzó alkalmi dohányosokat" ugyanakkor a visszaesés veszélye fenyegetheti az ANDT-k használatával. ${ }^{12,22}$ Vizsgálatunkban az alkalmi dohányzók aránya $(30,4 \%)$ lényegesen magasabb a hazai reprezentatív kutatások hasonló korcsoportjaihoz képest $(3-4 \%),{ }^{28,36}$ azonban szinte megegyezett egy korábbi, szintén zenei fesztiválozók körében végzett vizsgálatban találtakkal $(30,9 \%){ }^{38}$ Eredményeink rávilágítanak arra, hogy a zenei fesztiválok fiatal felnőtt látogatói körében kiemelkedően magas az alkalmi dohányosok aránya, akik az ANDT-ket is előszeretettel próbálják ki. Ezt a csoportot ún. társasági dohányosoknak is nevezik, akikre jellemző, hogy csak barátaik körében, illetve társasági eseményeken (például buliban, bárokban, fesztiválon), általában alkoholfogyasztás kíséretében, a baráti csoporthoz tartozás érdekében dohányoznak. ${ }^{22} \mathrm{~A}$ társasági dohányosok többnyire nem tekintik magukat dohányzónak, noha egészségüket kétségtelenül veszélyeztetik, a nikotinfüggőség kimutatható náluk és könnyen rendszeresen dohányzóvá válhatnak. ${ }^{22}$ Gyakran annak ellenére dohányoznak, hogy azt nem élvezik, az alapvetően nemdohányzó identitásuk megtörése pedig jelentős diszkomfortot okozhat számukra. 22

Több tanulmány is alátámasztja, hogy a zenei fesztiválok látogatói körében gyakoribbak a kockázatkereső magatartások, mint például a túlzott mértékű alkohol-, dohánytermék- és illegális szerhasználat. 24,26,46 Fesztivállátogatók körében a veszélyes mértékű alkoholfogyasztás prevalenciájáról kevés adat áll rendelkezésre, azonban a mintánkban találtakhoz hasonlóan nagy arányú problémás alkoholfogyasztást tártak fel ausztrál zenei fesztivállátogatók körében. ${ }^{46}$ Mintánk speciális jellegéből adódóan az alkoholhasználati eredményeket általánosítani nem lehet a hasonló korú, felsőoktatásban tanuló fiatalokra, akik körében lényegesen alacsonyabb mértékú a kockázatos alkoholfogyasztás gyakorisága. ${ }^{12,23,47,48}$ A fokozottabb szenzoros élménykereső magatartás ugyancsak szoros összefüggést mutatott a többféle ANDT-használattal, amelyet más vizsgálatok is alátámasztanak.1,12,21 Emellett mintánkban a férfiak nagyobb valószínúséggel számoltak be többféle ANDT-használatról, mint a nők. A serdülőkor és fiatal felnőttkor során a férfiak körében magasabb szenzoros élménykereső hajlam tapasztalható, amely ráadásul később és lassabban csökken, mint a nők esetében. ${ }^{49}$ Továbbá kulturális tényezők is erősithetik a szenzoros élménykeresés hosszabb és kifejezettebb fennállását a férfiaknál. ${ }^{49}$ Ez magyarázhatja mind az ANDThasználat, mind a veszélyes mértékú alkoholfogyasztás gyakoribb előfordulását mintánk férfi válaszadói körében a nőknél tapasztaltakhoz képest.

Eredményeink alapján a felsőoktatásban tanuló, szabadtéri zenei fesztiválon részt vevő fiatal felnőttek ANDT-használata számottevőnek mondható. Az ANDT-használók két kiemelt kockázati csoportját azonosítottuk, nevezetesen a társasági dohányzókat, akikre az alkalmi dohányzás mellett az ANDT-k kipróbálása és alkalmi használata jellemző, valamint a politoxikománokat, akik rendszeresen dohányoznak, problémás alkoholhasználók és többes ANDThasználók. A fiatal felnőtt korosztályban is szükség lenne többszintű dohányzásprevenciós tevékenységekre. A hazai dohányzással kapcsolatos felmérések és feltételezhetően az intervenciók túlnyomó többsége elsősorban a cigaretta használatra fókuszál, 
mellőzve az egyéb dohánytermékeket, amelyeknek használata azonban nem nevezhető elenyészőnek. ${ }^{50}$ A fiatal felnőttek gyakran eltérően vélekednek az ANDT-kről és a cigarettázásról, noha mindkét termékcsoport egyaránt dohányterméknek minősül számos egészségre ártalmas hatással. További problémaként merülhet fel, hogy az ANDT-ket használó fiatalok egyáltalán nem tekintik magukat dohányzónak, különösen, ha alkalmi dohányzók. ${ }^{12}$ Mindezek miatt szükséges lenne, hogy a dohányzásprevenciós kampányok újfajta, kifejezetten a fiatalokat megcélzó üzeneteket hordozzanak. Többek között az újdonságkeresés ésszerü célpont lehetne, vagy a dohánytermékek divatos, társadalmilag elfogadott mivoltának vitatása is megfontolandó. Továbbá az intervenciók hangsúlyozhatnák a manipulatív dohányipar elleni lázadást, mint újfajta progresszív gondolkodásmódot. ${ }^{51}$ Magyarországon személyes, telefonos vagy internetes leszokás-támogatási módszerek is elérhetôk, azonban a felsőoktatásban tanuló és leszokni szándékozó hallgatók körében mindezek valószínúleg nem eléggé ismertek. Mivel a hazai felsőoktatási intézmények területén tilos a dohányzás, a felsőoktatásban is szükség volna átfogó és a leginkább veszélyeztetett hallgatói csoportokat célzó dohányzásprevencióra, amely a dohánytermékek teljes spektrumát figyelembe venné. Kiemelt kockázati csoportként említhetők a fokozottan szenzoros élménykereső, alkalmanként cigarettázó fiatalok, akik tanulmányunkban és más vizsgálatokban is nagyobb valószínúséggel használtak ANDT-ket. ${ }^{12,21} \mathrm{Az}$ alkalmanként dohányzók, mivel nem tekintik magukat dohányosnak, nem érzik szükségét a leszokásnak. ${ }^{22,52}$ Éppen ezért esetükben a dohányzásra ösztönző ingerhelyzetekben - mint például alkoholfogyasztáskor - alkalmazható viselkedésváltoztató technikák elsajátítása volna hasznos. ${ }^{47} \mathrm{~A}$ fiatal felnőttek által látogatott szórakozóhelyeken, illetve a felsőoktatási intézményekben a beltéri dohányzás korlátozása mellett kültéren is megfontolandó lenne a dohányzás korlátozása a társasági dohányzás visszaszorítása érdekében. ${ }^{22,52}$ Ezért az alkalmi dohányzás abbahagyását is támogatni kellene megfelelö, a korosztály sajátosságait szem előtt tartó intervenciókkal. ${ }^{52}$ A közösségi médiaalapú intervencióknak kiemelt szerepe lehetne a fiatal korosztály dohányzással kapcsolatos attitűdjének formálásában és leszokás-támogatásában, ${ }^{53}$ azonban elengedhetetlen, hogy az ilyen típusú intervenciók is minél szélesebb körben ismertek legyenek a célpopuláció körében.

\section{KÖSZÖNETNYILVÁNITTÁS}

A szerzők köszönetüket fejezik ki a (korábbi) Nemzeti Egészségfejlesztési Intézet munkatársainak az adatfelvételben nyújtott segítségükért. 
1. táblázat: A minta leíró jellemzői és összehasonlítása az alternativ nikotinos és dohánytermékek (ANDT) használata* alapján

\begin{tabular}{|c|c|c|c|c|c|}
\hline Változó & $\begin{array}{l}\text { Teljes minta } \\
\qquad(n=523)\end{array}$ & $\begin{array}{c}\text { Nem használ ANDT-t, } \\
n=193(36,9 \%)\end{array}$ & $\begin{array}{l}\text { Egyféle ANDT-t használ, } \\
\qquad n=255 \text { (48,8\%) }\end{array}$ & $\begin{array}{c}\geq 2 \text { ANDT-t használ, } \\
n=75(14,3 \%)\end{array}$ & p-érték \\
\hline \multicolumn{6}{|l|}{ Korcsoport, n (\%) } \\
\hline 18-25 éves & $416(79,5)$ & $137(32,9)$ & $216(51,9)$ & $63(15,1)$ & 0,001 \\
\hline 26-35 éves & $107(20,5)$ & $56(52,3)$ & $39(36,4)$ & $12(11,2)$ & \\
\hline \multicolumn{6}{|l|}{ Nem, $n(\%)$} \\
\hline Férfi & $285(54,8)$ & $105(36,8)$ & $127(44,6)$ & $53(18,6)$ & 0,003 \\
\hline Nő & $235(45,2)$ & $88(37,4)$ & $127(54,0)$ & $20(8,5)$ & \\
\hline \multicolumn{6}{|l|}{ Tanulmány, n (\%) } \\
\hline Egészségorientált & $91(18,1)$ & $31(34,1)$ & $49(53,8)$ & $11(12,1)$ & \\
\hline Bölcsész & $46(9,1)$ & $17(37,0)$ & $23(50,0)$ & $6(13,0)$ & 0,561 \\
\hline Nem egészségorientált & $256(50,8)$ & $88(34,4)$ & $132(51,6)$ & $36(14,1)$ & \\
\hline Egyéb/nem tanul & $111(22,0)$ & $47(42,3)$ & $45(40,5)$ & $19(17,1)$ & \\
\hline \multicolumn{6}{|l|}{ Költőpénz / hó, n (\%) } \\
\hline$<30000 \mathrm{Ft}$ & $296(57,3)$ & $94(31,8)$ & $155(52,4)$ & $47(15,9)$ & 0,030 \\
\hline$\geq 30000 \mathrm{Ft}$ & $221(42,7)$ & $95(43,0)$ & $99(44,8)$ & $27(12,2)$ & \\
\hline \multicolumn{6}{|l|}{ Munkavállalás, n (\%) } \\
\hline Nem & $191(40,1)$ & $76(39,8)$ & $87(45,5)$ & $28(14,7)$ & 0,339 \\
\hline Igen & $285(59,9)$ & $97(34,0)$ & $149(52,3)$ & $39(13,7)$ & \\
\hline \multicolumn{6}{|l|}{ Aktuális dohányzás, n (\%) } \\
\hline Nem dohányzik & $263(50,7)$ & $122(46,4)$ & $124(47,1)$ & $17(6,5)$ & \\
\hline Alkalmanként & $158(30,4)$ & $41(25,9)$ & $87(55,1)$ & $30(19,0)$ & $<0,001$ \\
\hline Naponta & $98(18,9)$ & $30(30,6)$ & $41(41,8)$ & $27(27,6)$ & \\
\hline Szenzoros élménykeresés, átlag (SD) & $17,9(5,74)$ & $16,5(5,88)$ & $18,3(5,24)$ & $20,4(6,10)$ & $<0,001$ \\
\hline \multicolumn{6}{|l|}{ AUDIT, n (\%) } \\
\hline Nem problémás alkoholhasználó & $170(34,7)$ & $78(45,9)$ & $83(48,8)$ & $9(5,3)$ & $<0,001$ \\
\hline Problémás alkoholhasználó & $320(65,3)$ & $106(33,1)$ & $151(47,2)$ & $63(19,7)$ & \\
\hline
\end{tabular}

Megjegyzés: *Alkalmankénti és legalább havi gyakoriságú használat együttesen.

Forrás: saját szerkesztés 
2. táblázat: Az alternatív nikotinos és dohánytermékek (ANDT-k) használatának gyakorisága fiatal felnőttek körében dohányzói státusz szerint

\begin{tabular}{|c|c|c|}
\hline ANDT-használat* & Egyféle ANDT-t használ, n (\%) & 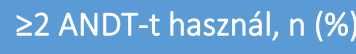 \\
\hline \multicolumn{3}{|l|}{ Nem dohányzók } \\
\hline Vízipipa & $119(46,3)$ & $15(5,8)$ \\
\hline E-cigaretta & $1(0,4)$ & $1(0,4)$ \\
\hline Szivar & $0(0,0)$ & $12(4,7)$ \\
\hline Szivarka & $2(0,8)$ & $6(2,3)$ \\
\hline Pipa & $0(0,0)$ & $3(1,2)$ \\
\hline Füstmentes dohánytermékek & $2(0,8)$ & $5(2,0)$ \\
\hline \multicolumn{3}{|l|}{ Alkalmanként dohányzók } \\
\hline Vízipipa & $83(53,2)$ & $23(14,7)$ \\
\hline E-cigaretta & $2(1,3)$ & $14(9,0)$ \\
\hline Szivar & $0(0,0)$ & $18(11,8)$ \\
\hline Szivarka & $1(0,6)$ & $16(10,4)$ \\
\hline Pipa & $1(0,6)$ & $9(5,8)$ \\
\hline Füstmentes dohánytermékek & $0(0,0)$ & $5(3,3)$ \\
\hline \multicolumn{3}{|l|}{ Naponta dohányzók } \\
\hline Vízipipa & $39(40,2)$ & $22(22,7)$ \\
\hline E-cigaretta & $2(2,1)$ & $12(12,5)$ \\
\hline Szivar & $0(0,0)$ & $42(8,3)$ \\
\hline Szivarka & $0(0,0)$ & $9(9,5)$ \\
\hline Pipa & $0(0,0)$ & $6(6,3)$ \\
\hline Füstmentes dohánytermékek & $0(0,0)$ & $7(7,4)$ \\
\hline
\end{tabular}

Megjegyzés: *Alkalmankénti és legalább havi gyakoriságú használat együttesen.

Forrás: saját szerkesztés 
3. táblázat: Az alternativ nikotinos és dohánytermékek (ANDT) használatának elörejelzői többváltozós logisztikus regressziós modellekben

\begin{tabular}{|c|c|c|c|c|c|c|c|c|c|}
\hline \multirow[t]{2}{*}{ Változó } & \multicolumn{3}{|c|}{$\begin{array}{l}\text { Egyféle ANDT-t használ vs. } \\
\text { nem használ ANDT-t ( } n=354)\end{array}$} & \multicolumn{3}{|c|}{$\begin{array}{l}\geq 2 \text { ANDT-t használ vs. } \\
\text { nem használ ANDT-t }(n=205)\end{array}$} & \multicolumn{3}{|c|}{$\begin{array}{l}\geq 2 \text { ANDT-t használ vs. } \\
\text { egyféle ANDT-t használ ( } n=261 \text { ) }\end{array}$} \\
\hline & $\mathrm{EH}$ & $95 \% \mathrm{Cl}$ & p-érték & $\mathrm{EH}$ & $95 \% \mathrm{Cl}$ & p-érték & $\mathrm{EH}$ & $95 \% \mathrm{Cl}$ & p-érték \\
\hline \multicolumn{10}{|l|}{ Korcsoport } \\
\hline 18-25 éves & 1,85 & $0,99-3,44$ & 0,054 & 1,29 & $0,41-4,08$ & 0,664 & 0,94 & $0,31-2,86$ & 0,914 \\
\hline 26-35 éves & Ref. & & & Ref. & & & Ref. & & \\
\hline \multicolumn{10}{|l|}{ Nem } \\
\hline Férfi & 0,79 & $0,50-1,26$ & 0,319 & 2,98 & $1,35-6,58$ & 0,007 & 2,40 & $1,18-4,88$ & 0,016 \\
\hline Nő & Ref. & & & Ref. & & & Ref. & & \\
\hline \multicolumn{10}{|l|}{ Tanulmány } \\
\hline Egészségorientált & Ref. & & & Ref. & & & Ref. & & \\
\hline Bölcsész & 0,80 & $0,35-1,86$ & 0,607 & 2,28 & $0,52-9,98$ & 0,275 & 2,03 & $0,54-7,57$ & 0,293 \\
\hline Nem egészségorientált & 1,04 & $0,58-1,89$ & 0,891 & 1,11 & $0,39-3,11$ & 0,847 & 1,09 & $0,44-2,70$ & 0,859 \\
\hline Egyéb/nem tanul & 0,67 & $0,32-1,41$ & 0,289 & 0,87 & $0,25-2,97$ & 0,824 & 1,35 & $0,43-4,22$ & 0,609 \\
\hline \multicolumn{10}{|l|}{ Költőpénz / hó } \\
\hline$<30000 \mathrm{Ft}$ & 1,38 & $0,86-2,22$ & 0,183 & 2,98 & $1,29-6,86$ & 0,010 & 1,63 & $0,77-3,46$ & 0,202 \\
\hline$\geq 30000 \mathrm{Ft}$ & Ref. & & & Ref. & & & Ref. & & \\
\hline \multicolumn{10}{|l|}{ Munkavállalás } \\
\hline Nem & 0,87 & $0,54-1,38$ & 0,543 & 1,29 & $0,60-2,77$ & 0,520 & 1,53 & $0,77-3,04$ & 0,221 \\
\hline Igen & Ref. & & & Ref. & & & Ref. & & \\
\hline \multicolumn{10}{|l|}{ Aktuális dohányzás } \\
\hline Nem dohányzik & Ref. & & & Ref. & & & Ref. & & \\
\hline Alkalmanként & 1,89 & $1,11-3,20$ & 0,019 & 5,97 & $\begin{array}{l}2,35- \\
15,14\end{array}$ & $<0,001$ & 2,19 & $0,98-4,88$ & 0,056 \\
\hline Naponta & 0,86 & $0,45-1,67$ & 0,661 & 4,41 & $\begin{array}{l}1,69- \\
11,52\end{array}$ & 0,002 & 4,35 & $\begin{array}{l}1,79- \\
10,56\end{array}$ & 0,001 \\
\hline Szenzoros élménykeresés & 1,03 & $0,99-1,08$ & 0,140 & 1,08 & $1,01-1,15$ & 0,033 & 1,06 & $0,99-1,13$ & 0,088 \\
\hline \multicolumn{10}{|l|}{ AUDIT } \\
\hline Nem problémás alkoholhasználó & Ref. & & & Ref. & & & Ref. & & \\
\hline Problémás alkoholhasználó & 1,02 & $0,62-1,66$ & 0,946 & 3,14 & $1,12-8,76$ & 0,029 & 2,78 & $1,07-7,20$ & 0,035 \\
\hline Nagelkerke $\mathrm{R}^{2}$ & \multicolumn{3}{|c|}{$9,4 \%$} & \multicolumn{3}{|c|}{$35,2 \%$} & \multicolumn{3}{|c|}{$22,9 \%$} \\
\hline
\end{tabular}

Megjegyzés: A táblázatban félkövér kiemeléssel jelöltük a p<0,05 eredményeket.

Forrás: saját szerkesztés 
1. ábra: Az alternatív nikotinos és dohánytermékek használatának gyakorisága fiatal felnőttek körében

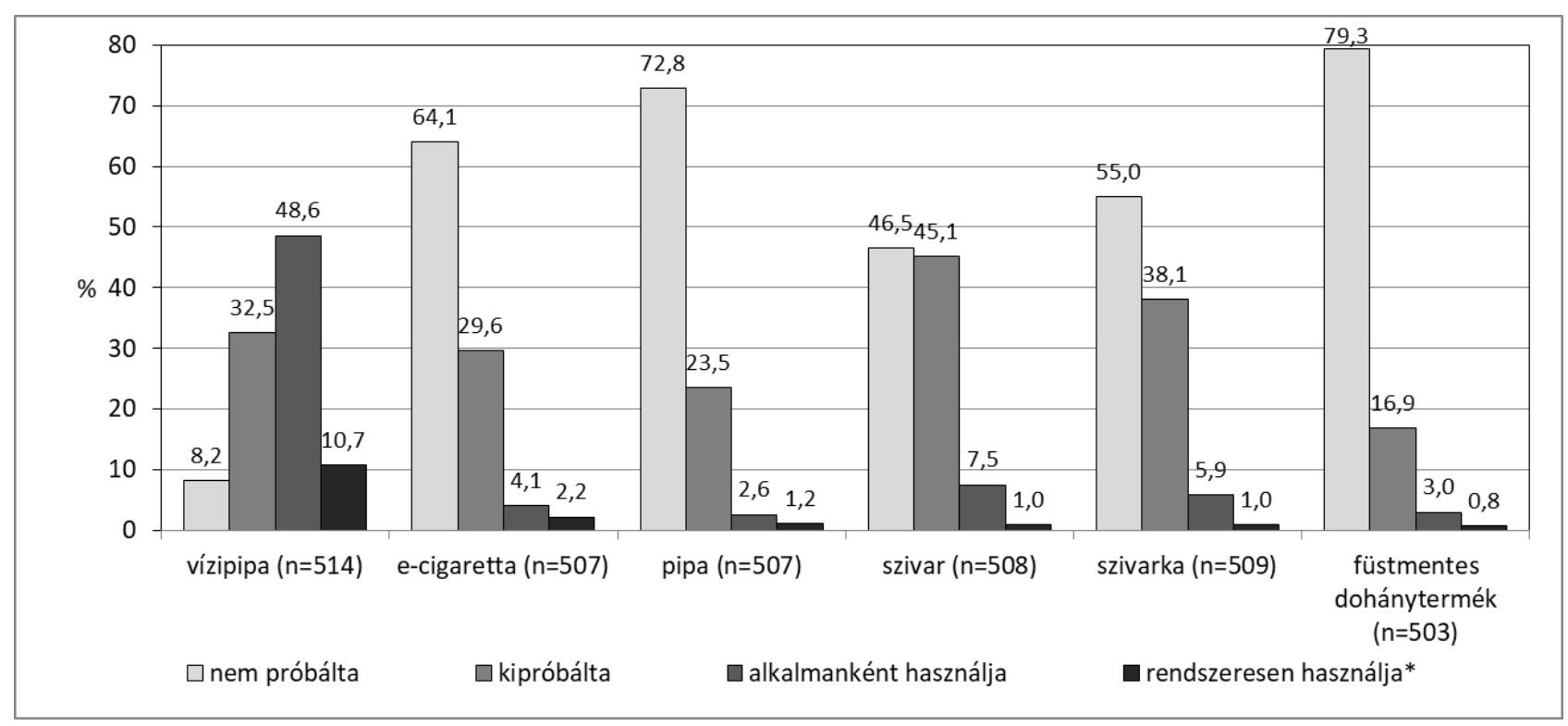

Megjegyzés: *Legalább havonta egyszer használta.

Forrás: saját szerkesztés

\section{HIVATKOZÁSOK}

\footnotetext{
${ }^{1}$ Doran N, Trim RS. Correlates of other tobacco use in a community sample of young adults. Addict Behav. 2015;51:131-135. doi:10.1016/j.addbeh.2015.07.023

${ }^{2}$ Lauterstein D, Hoshino R, Gordon T, et al. The changing face of tobacco use among United States youth. Curr Drug Abuse Rev. 2014;7(1):29-43.

${ }^{3}$ O'Connor RJ, McNeill A, Borland R, et al. Smokers' beliefs about the relative safety of other tobacco products: findings from the ITC collaboration. Nicotine Tob Res. 2007;9(10):1033-1042. doi:10.1080/14622200701591583

${ }^{4}$ Glasser AM, Collins L, Pearson JL, et al. Overview of electronic nicotine delivery systems: a systematic review. Am J Prev Med. 2017;52(2):e33-e66. doi:10.1016/j.amepre.2016.10.036

${ }^{5}$ Brown AK, Nagelhout GE, van den Putte B, et al. Trends and socioeconomic differences in roll-your-own tobacco use: findings from the ITC Europe Surveys. Tob Control. 2015;24(Suppl 3):iii11-iii16.

doi:10.1136/tobaccocontrol-2014-051986

${ }^{6}$ O'Connor RJ. Non-cigarette tobacco products: what have we learnt and where are we headed? Tob Control. 2012;21(2):181-190. doi:10.1136/tobaccocontrol-2011-050281

7 Drope J, Cahn Z, Kennedy R, et al. Key issues surrounding the health impacts of electronic nicotine delivery systems (ENDS) and other sources of nicotine: Tobacco Control in the Era of ENDS. CA Cancer J Clin. 2017;67(6):449-471. doi:10.3322/caac. 21413

${ }^{8}$ Doran N, Godfrey KM, Myers MG. Hookah use predicts cigarette smoking progression among college smokers. Nicotine Tob Res. 2015;17(11):1347-1353. doi:10.1093/ntr/ntu343

${ }^{9}$ Meier EM, Tackett AP, Miller MB, et al. Which nicotine products are gateways to regular use? First-tried tobacco and current use in college students. Am J Prev Med. 2015;48(1 Suppl 1):S86-93. doi:10.1016/j.amepre.2014.09.018

${ }^{10}$ Soneji S, Barrington-Trimis JL, Wills TA, et al. Association between initial use of e-cigarettes and subsequent cigarette smoking among adolescents and young adults: a systematic review and meta-analysis. JAMA Pediatr. 2017;171(8):788. doi:10.1001/jamapediatrics.2017.1488

${ }^{11}$ Rigotti NA, Lee JE, Wechsler H. US college students' use of tobacco products: results of a national survey. JAMA. 2000;284(6):699-705.

12 Enofe N, Berg CJ, Nehl EJ. Alternative tobacco use among college students: who is at highest risk? Am J Health Behav. 2014;38(2):180-189. doi:10.5993/AJHB.38.2.3
} 
${ }^{13}$ Loukas A, Batanova M, Fernandez A, et al. Changes in use of cigarettes and non-cigarette alternative products among college students. Addict Behav. 2015;49:46-51. doi:10.1016/j.addbeh.2015.05.005

${ }^{14}$ Latimer LA, Batanova M, Loukas A. Prevalence and harm perceptions of various tobacco products among college students. Nicotine Tob Res. 2014;16(5):519-526. doi:10.1093/ntr/ntt174

${ }^{15}$ AkI EA, Jawad M, Lam WY, et al. Motives, beliefs and attitudes towards waterpipe tobacco smoking: a systematic review. Harm Reduct J. 2013;10:12. doi:10.1186/1477-7517-10-12

${ }^{16}$ Carpenter CM, Wayne GF, Pauly JL, et al. New cigarette brands with flavors that appeal to youth: tobacco marketing strategies. Health Aff (Millwood). 2005;24(6):1601-1610. doi:10.1377/hlthaff.24.6.1601

${ }^{17}$ Brown CJ, Cheng JM. Electronic cigarettes: product characterisation and design considerations. Tob Control. 2014;23(suppl 2):ii4-ii10. doi:10.1136/tobaccocontrol-2013-051476

${ }^{18}$ Zhu S-H, Sun JY, Bonnevie E, et al. Four hundred and sixty brands of e-cigarettes and counting: implications for product regulation. Tob Control. 2014;23(suppl 3):iii3-iii9. doi:10.1136/tobaccocontrol-2014-051670

${ }^{19}$ Sutfin EL, Reboussin BA, Debinski B, et al. The impact of trying electronic cigarettes on cigarette smoking by college students: a prospective analysis. Am J Public Health. 2015;105(8):e83-e89. doi:10.2105/AJPH.2015.302707

20 Mayer K, Lukács A, Pauler G. A 8-tételes Szenzoros Élménykeresés Skála (BSSS-8) magyarországi adaptálása. Mentálhig és Pszichoszomatika. 2012;13(3):297-312. doi:10.1556/Mental.13.2012.3.3

${ }^{21}$ Case KR, Loukas A, Harrell MB, et al. The association between sensation seeking and e-cigarette use in Texas young adults: A cross-sectional study. J Am Coll Health. 2017;65(4):277-285. doi:10.1080/07448481.2017.1282487

22 Hoek J, Maubach N, Stevenson R, et al. Social smokers' management of conflicted identities. Tob Control. 2013;22(4):261-265. doi:10.1136/tobaccocontrol-2011-050176

${ }^{23}$ Evans-Polce R, Lanza S, Maggs J. Heterogeneity of alcohol, tobacco, and other substance use behaviors in U.S. college students: A latent class analysis. Addict Behav. 2016;53:80-85. doi:10.1016/j.addbeh.2015.10.010

${ }^{24}$ Hesse M, Tutenges S, Schliewe S. The use of tobacco and cannabis at an international music festival. Eur Addict Res. 2010;16(4):208-212. doi:10.1159/000317250

${ }^{25}$ Ábrám Z, Bálint JL, Ferencz L, et al. Marosvásárhelyi Félsziget Fesztivál jövőképe - drogfogyasztási adatok. Egészségtudomány. 2014;58(4):59.

${ }^{26}$ Mackul'ak T, Grabic R, Gál M, et al. Evaluation of different smoking habits during music festivals through wastewater analysis. Environ Toxicol Pharmacol. 2015;40(3):1015-1020. doi:10.1016/j.etap.2015.10.007

${ }^{27}$ Szakleírások A-Z. http://www.felvi.hu/felveteli/szakok_kepzesek/szakleirasok. (Elérve: 2019.03.20.)

${ }^{28}$ Cselkó Z, Kovács G, Horváth I. A dohányzás helyzete Magyarországon. In: Tokaji K (ed.) Európai lakossági egészségfelmérés, 2014. Központi Statisztikai Hivatal, Budapest, 2018. pp. 85-112.

${ }^{29}$ Hoyle RH. Reliability and validity of a brief measure of sensation seeking. Individ Differ. 2002;32.

doi:10.1016/S0191-8869(01)00032-0

${ }^{30}$ Babor TF, Higgins-Biddle JC, Saunders JC, et al. The Alcohol Use Disorders Identification Test: Guidelines for use in primary care, 2nd edition. World Health Organization, Geneva, 2001.

${ }^{31}$ Reinert DF, Allen JP. The Alcohol Use Disorders Identification Test (AUDIT): a review of recent research. Alcohol Clin Exp Res. 2002;26(2):272-279.

32 Malone RE, Yerger $V$, Pearson C. Cigar risk perceptions in focus groups of urban African American youth. J Subst Abuse. 2001;13(4):549-561.

${ }^{33}$ European Commission. Special Eurobarometer 458 "Attitudes of Europeans towards tobacco and electronic cigarettes." 2017. http://ec.europa.eu/commfrontoffice/publicopinion/index.cfm/Survey/getSurveyDetail/yearFrom/1974/yearTo/2017/surveyKy/2146. (Elérve: 2019.03.20.)

34 Demjén T, Kiss J, Formanek-Balku E. Az Egészségügyi Világszervezet Nemzetközi Ifjúsági Dohányzás Felmérésének 2016. évi hazai megvalósításáról - Záró tanulmány. Dohányzás Fókuszpont, Budapest, 2016. http://www.fokuszpont.dohanyzasvisszaszoritasa.hu/sites/default/files/01_GYTS_2016_osszefoglalo_tanulmany.pdf (Elérve: 2019.03.20.) ${ }^{35}$ Pénzes M, Foley KL, Balázs $P$, et al. Patterns of alternative tobacco product experimentation among ever smoker adolescents. Cent Eur J Public Health. 2019;27(1):3-9. doi:10.21101/cejph.a5364

${ }^{36}$ Balku E, Demjén T, Kimmel Zs, et al. Felnőtt Dohányzás Felmérés 2013. Országos Egészségfejlesztési Intézet, Budapest, 2014. http://www.fokuszpont.dohanyzasvisszaszoritasa.hu/sites/default/files/17_evnel_idosebb_lakossag_dohanyzas_felmeres_II_honlapra_20140128_v2.pdf (Elérve: 2019.03.20.)

37 Sutfin EL, McCoy TP, Morrell HER, et al. Electronic cigarette use by college students. Drug Alcohol Depend. 2013;131(3):214-221. doi:10.1016/j.drugalcdep.2013.05.001

38 Pénzes M, Pongor V, Kimmel Zs, et al. Elektronikus cigaretta használat felsőoktatásban tanuló hallgatók körében. Lege Artis Med. 2016;26(3):107-114.

39 Pénzes M, Foley KL, Balázs P, et al. Intention to experiment with e-cigarettes in a cross-sectional survey of undergraduate university students in Hungary. Subst Use Misuse. 2016;51(9):1083-1092. doi:10.3109/10826084.2016.1160116 
${ }^{40}$ Balogh E, Faubl N, Riemenschneider H, et al. Cigarette, waterpipe and e-cigarette use among an international sample of medical students. Cross-sectional multicenter study in Germany and Hungary. BMC Public Health. 2018;18(1):591. doi:10.1186/s12889-018-5494-6

${ }^{41}$ Backinger CL, Fagan P, O'Connell ME, et al. Use of other tobacco products among U.S. adult cigarette smokers: Prevalence, trends and correlates. Addict Behav. 2008;33(3):472-489. doi:10.1016/j.addbeh.2007.10.009

${ }^{42}$ Agaku IT, Filippidis FT, Vardavas Cl, et al. Poly-tobacco use among adults in 44 countries during 2008-2012: Evidence for an integrative and comprehensive approach in tobacco control. Drug Alcohol Depend. 2014;139:60-70.

doi:10.1016/j.drugalcdep.2014.03.003

${ }^{43}$ Vijayaraghavan M, Pierce JP, White M, et al. Differential use of other tobacco products among current and former cigarette smokers by income level. Addict Behav. 2014;39(10):1452-1458. doi:10.1016/j.addbeh.2014.05.029

${ }^{44}$ Nemzeti Adó- és Vámhivatal: Dohánygyártmányok kiskereskedelmi eladási ára.

https://nav.gov.hu/nav/ado/jovedeki_ado/tajekoztatok_informaciok/Dohanygyartmanyok_kiskereskedelmi_eladasi_ara/alkalmazhato_dohanygyartmany (Elérve: 2019.07.07.)

${ }^{45}$ Lopez AA, Eissenberg $\mathrm{T}$, Jaafar M, et al. Now is the time to advocate for interventions designed specifically to prevent and control waterpipe tobacco smoking. Addict Behav. 2017;66:41-47. doi:10.1016/j.addbeh.2016.11.008

${ }^{46}$ Bowring AL, Gouillou M, Hellard M, et al. Comparing short versions of the AUDIT in a community-based survey of young people. BMC Public Health. 2013;13(1). doi:10.1186/1471-2458-13-301

47 Sutfin EL, McCoy TP, Berg CJ, et al. Tobacco use by college students: a comparison of daily and nondaily smokers. Am J Health Behav. 2012;36(2):218-229. doi:10.5993/AJHB.36.2.7

48 Terebessy A, Czeglédi E, Balla BC, et al. Medical students' health behaviour and self-reported mental health status by their country of origin: a cross-sectional study. BMC Psychiatry. 2016;16:171. doi:10.1186/s12888-016-0884-8

${ }^{49}$ Shulman EP, Harden KP, Chein JM, et al. Sex differences in the developmental trajectories of impulse control and sensation-seeking from early adolescence to early adulthood. J Youth Adolesc. 2015;44(1):1-17.

doi:10.1007/s10964-014-0116-9

50 Fekete M, Pénzes M, Balázs P. Iskolai dohányzás-prevenciós programok jellegzetességei. Egészségtudomány. 2016;60(2):55-69.

${ }^{51}$ Berg CJ, Haardörfer R, Lewis M, et al. DECOY: Documenting Experiences with Cigarettes and Other Tobacco in Young Adults. Am J Health Behav. 2016;40(3):310-321. doi:10.5993/AJHB.40.3.3

52 Waters K, Harris K, Hall S, et al. Characteristics of social smoking among college students. J Am Coll Health J ACH. 2006;55(3):133-139. doi:10.3200/JACH.55.3.133-139

53 Pócs D, Kovács R, Óvári T, etal. A dohányzás visszaszorítása a Facebook segítségével a 14-35 éves korosztály körében. Orv Hetil. 2019;160(6):220-227. doi:10.1556/650.2019.31314 